\title{
THE NOVEMBER MEETING IN MANHATTAN
}

The three hundred eighty-second meeting of the American Mathematical Society was held at Kansas State College, Manhattan, Kansas, on Friday and Saturday, November 21-22, 1941. The attendance was about eighty including the following forty-seven members of the Society:

A. A. Albert, M. N. Arnoldy, W. L. Ayres, R. W. Babcock, Wealthy Babcock, F. L. Black, L. M. Blumenthal, W. C. Brenke, C. C. Camp, R. D. Daugherty, H. P. Doole, Paul Eberhart, W. E. Ferguson, Cornelius Gouwens, O. H. Hamilton, J. J. L. Hinrichsen, D. L. Holl, W. C. Janes, H. E. Jordan, D. E. Kibbey, E. H. Larguier, P. E. Lewis, A. T. Lonseth, J. V. McKelvey, Anna Marm, U. G. Mitchell, T. A. Mossman, G. C. Munro, E. N. Oberg, R. S. Pate, T. A. Pierce, P. S. Pretz, G. B. Price, P. G. Robinson, D. H. Rock, L. L. Runge, G. E. Schweigert, C. E. Sealander, M. E. Shanks, D. T. Sigley, E. R. Smith, G. W. Smith, E. B. Stouffer, W. T. Stratton, C. B. Tucker, L. E. Ward, J. W. T. Youngs.

The meeting opened Friday afternoon in Mathematics Hall with a session for short papers, Professor W. T. Stratton presiding. Following this, Professor G. B. Price gave an address entitled Linear extensions. Professor L. M. Blumenthal presided at this lecture. On Saturday morning in Willard Hall with Professor C. C. Camp presiding, Professor A. A. Albert gave an address with the title Some mathematical aspects of cryptography. The meeting closed with a second session of contributed papers with Dean E. B. Stouffer presiding.

The dinner on Friday evening was held at the Country Club on a hill with a fine view of Manhattan and the surrounding country. The number attending the dinner was eighty-two. Professor W. T. Stratton presided at the dinner. After musical selections by Miss Hilda Grossman, President F. D. Farrell of Kansas State College welcomed the mathematicians and Associate Secretary W. L. Ayres responded for the Society. Professor U. G. Mitchell spoke on mathematics as an intellectual invention and urged the training of mathematicians for the social sciences. Dean R. W. Babcock talked on mathematical contemporaries urging that students be taught to look on mathematics as a living science and be told of living mathematicians.

Titles and cross references to the abstracts of the papers read at this meeting follow below. Papers 1 to 5 were read Friday afternoon, papers 6 to 10 on Saturday morning, papers 11 to 13, whose abstract numbers are followed by the letter $t$, were read by title. Mr. R. H. Tripp and Mr. A. E. Engelbrecht were introduced by Professor D. L. Holl.

1. D. L. Holl: Consolidation of elastic earth layers. (Abstract 48-168.) 
2. A. A. Albert: Quadratic forms permitting composition. (Abstract 48-1-1.)

3. J. W. T. Youngs: Concerning arc-curves and basic sets. (Abstract 47-9-453.)

4. M. E. Shanks: Irreducible transformations of the discontinuum into continua. Preliminary report. (Abstract 48-1-97.)

5. J. J. L. Hinrichsen: Bounds for the libration points in a restricted problem of $n$ bodies. (Abstract 48-1-67.)

6. L. M. Blumenthal: Metric characterization of $n$-dimensional elliptic space $\mathcal{E}_{n r}$. Preliminary report. (Abstract 48-1-75.)

7. R. S. Pate: Functional homomorphisms. I. Preliminary report. (Abstract 48-1-17.)

8. G. C. Munro: Systems of linear differential equations with constant coefficients. (Abstract 48-1-45.)

9. R. H. Tripp: Bending of a thin plate having the form of a parallelogram. (Abstract 48-1-73.)

10. A. E. Engelbrecht: Circular plates with large deflections. (Abstract 48-1-63.)

11. C. V. Robinson: Spherical theorems of Helly type and congruence indices of spherical caps. (Abstract 47-11-482-t.)

12. R. H. Bruck and T. L. Wade: The number of independent components of the tensor ${ }_{[\alpha]} T_{i_{1}} \cdots i_{p}$. (Abstract 47-11-454-t.)

13. Isaac Opatowski: On the theory of lethal irradiation of microörganisms. II. (Abstract 48-1-69-t.)

W. L. Ayres, Associate Secretary 